\title{
Innovation and Development of English Translation in the Era of Internet +
}

\author{
Yao Lan \\ Shaanxi Technical College of Finance and Economics, Shaanxi, China, 712000
}

Keywords: Internet; English translation; Innovation

\begin{abstract}
With the continuous improvement of modern information technology, "Internet +" technology is becoming more and more mature, and is widely used in the development process of various industries. College English translation education, as an important major in College English education at the present stage in China, plays a very active role in training new English translators. However, the traditional college English translation teaching can no longer meet the actual needs of translators in China at this stage. Only by constantly innovating the teaching mode of College English translation and combining with the current information technology means, and constantly optimizing the curriculum system of College English translation, can the quality of College English translation teaching be improved accordingly. Based on this, this paper explores the innovation of College English translation teaching mode under the background of "Internet +".
\end{abstract}

With the deepening of economic globalization, the exchanges between countries are getting closer and closer. As one of the universal languages in the world, English plays a very active role in the exchanges between countries. Because of this, the demand for English translators in our country is getting higher and higher at the present stage. College English translation education is an important means of training English translators in China. Although the level of College English teaching has been greatly improved at this stage, the relevant teaching modes are not particularly mature in English translation teaching, which restricts the improvement of studentship translation level. With the constant maturity of Internet + technology, applying it to practical English translation teaching has a positive effect on innovating the teaching mode of College English translation and improving the quality of College English translation teaching.

\section{Problems in college English translation teaching at the present stage}

As shown in figure1, a detailed analysis is presented below. 


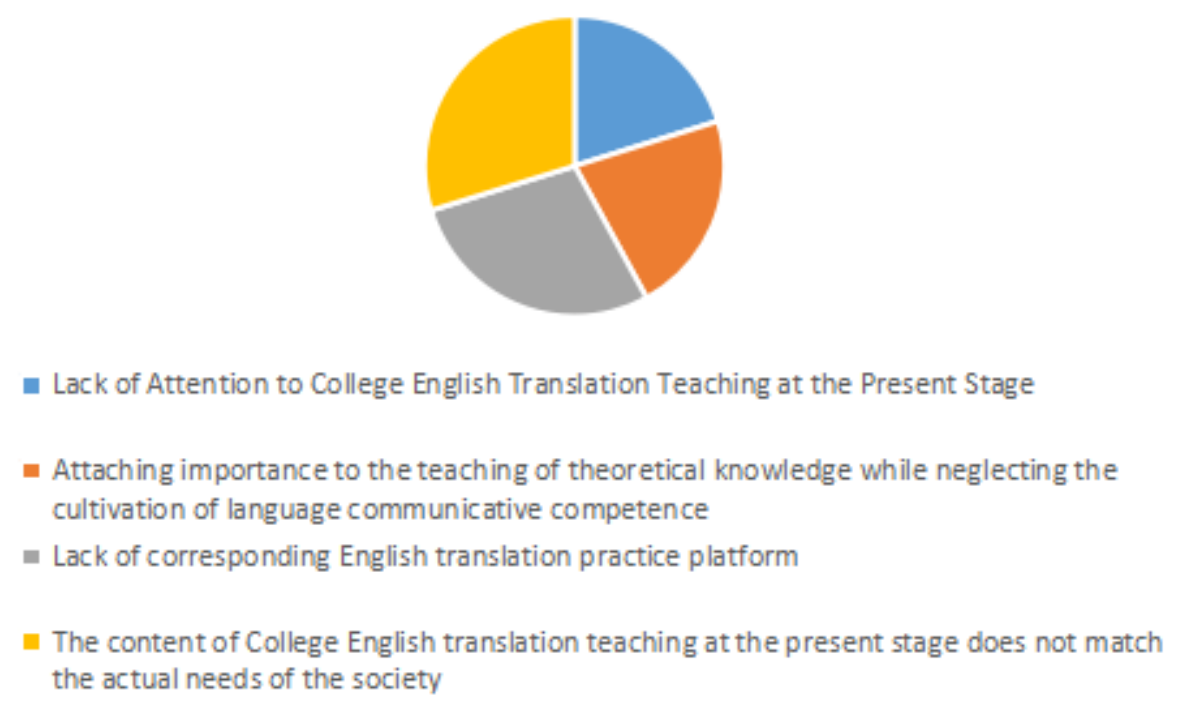

Figure 1. Problems in College English Translation Teaching at the Present Stage

\subsection{Lack of attention to college English translation teaching at the present stage}

Under the influence of exam-oriented education, the development of College English teaching in our country has been limited at the present stage, especially the teaching of College English translation. In the traditional college English teaching process, the teaching purpose is to enable students to achieve better results in the actual examination process and pass the CET- 4 and CET-6 smoothly. The higher the passing rate, the higher the reteaching ability and classroom teaching level. It is precisely because of the influence of examination-oriented education that college English teaching in our country often chooses the course content according to the actual examination content. In this way, it is easy to cause the limitations in the comprehensiveness of the teaching content, including English translation teaching. In the long-term College English teaching process, English translation teaching has not really been paid attention to. In the actual teaching process, the content of English translation is relatively small. Over time, English translation teaching has become a relatively weak subject in the development of College education.

\subsection{Attaching importance to the teaching of theoretical knowledge while neglecting the} cultivation of language communicative competence

Due to the influence of traditional teaching modes, in the process of College English teaching development, English translation teaching only stays at the level of theoretical knowledge teaching. In addition, most of the final examinations for college English translation majors are based on theoretical examinations, which do not attach enough importance to telecommunications competence and easily restrict the development of students' comprehensive English translation ability. However, there are some differences between English translation and other subjects. This subject is a course for students to improve their communicative competence after they have mastered the basic knowledge of English proficiently. If only theoretical teaching is emphasized while language communicative competence is neglected, although students can firmly grasp theoretical knowledge, it is only a talk on paper that can not effectively carry out real translators. 


\subsection{Lack of corresponding English translation practice platform}

Compared with other majors, College English translation majors have strong particularity, which is a combination of theory and practice. In the process of College English translation learning, students are required not only to have a solid theoretical knowledge base, but also to have a high demand for their language practice. Due to the limitations of various factors, colleges and universities at this stage have not established corresponding English translation practice platform, resulting in students only staying at the theoretical level in the process of learning relevant translation knowledge.

Although some universities have set up corresponding English translation practice platforms, their specifications and efficiency are still at a relatively primitive level. As a result, studentship practice is difficult to achieve. Because of the great differences in the level of economic development in China, the requirements for English translators are not the same, which makes English translation practice mere formality and lacks corresponding measures. The practice platform has brought great obstacles to the development of English translation comprehensive abilities.

\subsection{The content of college English translation teaching at the present stage does not match the actual needs of the society}

Although great progress has been made in the teaching of English translation in Colleges and universities in China at the present stage, and the corresponding teaching modes are improving day by day, the selection of teaching contents still tends to be traditional, and for many years, there has been no major change in the teaching contents of English translation. In addition, the traditional teaching modes can easily lead to the lack of theoretical and practical needs of College English translation teaching at the present stage. Matching occurs. At present, most college translation textbooks in China are based on English translation criteria and theories, and the content is relatively old, and they do not keep pace with the times. The defects of teaching content lead to studentship to effectively study college English translation, which poses a threat to the cultivation of students' comprehensive quality of English translation.

\section{Innovative teaching methods}

Under the background of Internet, English translation teaching can be innovated in the following aspects, as shown in figure 2.

\section{Optimizing the Course System}

Developing Communicative Teaching

Developing Micro-Course Resources

Promoting Autonomous Learning

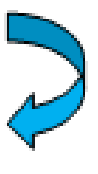

Figure 2. Innovative teaching methods 


\subsection{Optimizing the Course System}

Under the background of "Internet +", it is necessary to change the teaching mode in the new educational concept, so as to better meet the needs of the information age. For colleges and universities, they need to be able to establish a new English curriculum system and apply it to English teaching practice at the same time, so that students can learn English translation after they have mastered the basic knowledge of English. Specifically, colleges and universities can offer English translation elective courses, such as British and American film appreciation, newspaper and magazine articles reading and so on. They can also hold English translation lectures from time to time, so as to enable students to form a higher interest in English translation learning. The application of this method can not only help students to increase their vocabulary and reading speed, but also further improve the accuracy of English translation. It can also help more non-English majors to participate in translation teaching and make them develop faster on the basis of improving the overall level of students.

\subsection{Developing Communicative Teaching}

In College English translation teaching pool, the application of Internet technology can change the mode of glistening and teachers' speaking in the past. In translation class, students are no longer simply memorizing relevant knowledge. In English translation teaching activities, students can occupy a dominant position and become active learners of knowledge. For many students, they lack interest in translation to management theory, but they are very fond of foreign movies in their daily life. In this case, teachers can play English movies through the application of multimedia technology in class, and English dialogues appear on the screen.

In the process of playing the film, the teacher needs to analyze the English dialogue and compare it with Chinese. In the process, the students want to know how to translate the dialogue in the film. In this process, it can help students feel the differences in style between English and Chinese, and better realize the perception of English translation skills. After that, teachers need to integrate with the official audio materials to explain the non-English translation theory for students, so as to enable students to have a stronger initiative in learning translation theory and constantly improve the teaching level of English translation.

\subsection{Developing Micro-Course Resources}

In the process of the continuous development of information technology, colleges and universities also need to be able to establish a practical platform for college English translation. Through the construction of the platform, students can learn more space and time, so that they can have more chances to conduct practical translation exercises. In College education, the aim of College English curriculum is to help students apply it to practice on the basis of mastering basic English competence, and to possess certain English writing ability and communicative ability. To achieve this goal, it is necessary for students to have translation skills and abilities on the basis of basic English listening, speaking, reading and writing abilities.

But in actual teaching, influenced by studentship proficiency, students have different understandings when facing the translation teaching content. Therefore, teachers can publish teaching resources such as micro-videos and micro-classes on the platform, so that students can learn selectively according to the actual situation and learning needs. In this process, it can not only take care of the individual needs of different students, but also effectively realize the mobilization of denuclearizing autonomy. 


\subsection{Promoting autonomous learning}

In the process of English translation teaching, students are the main body. In practical teaching, teachers are required to cultivate autonomous learning ability and form their autonomous learning level in the process of continuous guidance. In specific learning, teacher's guidance is very important. Only by combining student subject with teacher's leading role, can we achieve good translation teaching effect. In the Internet era, with the emergence of translation tools and the rapid development of information technology, students will also have more opportunities to learn independently after class. Specifically, teachers can call on students to exchange skills, learning and experience of English translation in the group through the sub-knowledge of Hatcheck Group and QQ Group, so as to further improve their translation ability.

\section{Conclusion}

English translation is one of the most important courses in applied majors in Colleges and universities nowadays. It can also be said that it is a key course to cultivate characteristically ability in English. In the above, we have studied the innovation of College English translation teaching mode under the background of "Internet +". In the future, in the teaching of English translation in Colleges and universities, it is necessary to make full use of new technologies so as to continuously improve the level of translation teaching.

\section{References}

[1] Li Ling. Exploring the reform and development of College English Teaching in the era of "Internet +" [J]. Campus English, 2017 (45): 84-85.

[2] Ungulate Animal. Innovation of College English teaching mode under the background of "Internet +" [J]. Modern vocational education, 2017 (19): 120-121.

[3] Bhang Hui. On the practical significance of Internet + flipped classroom teaching mode in English Teaching in Independent Colleges [J]. Campus English, 2017 (25): 22.

[4] Huang Dan Ha. Innovative research on the teaching mode of College English translation under the background of "Internet +" [J]. Educational theory and practice, 2017, 37 (15): 53-54.

[5] Li Chi J. Lei. Research on the reform and development of College English Teaching under the background of "Internet +" [J]. Campus English, 2017 (11): 38. 